\title{
Assessment of Pseudoaffinity Chromatography Using Textile Dyes for Isolation of Buffalo Pituitary Luteinizing Hormone
}

\author{
Taruna Arora, ${ }^{1}$ Pankaj Patel, ${ }^{2}$ and K. Muralidhar ${ }^{1}$ \\ ${ }^{1}$ Hormone Research Laboratory, Department of Zoology, University of Delhi, Delhi 110007, India \\ ${ }^{2}$ School of Life Sciences, Devi Ahilya University, Indore 452001, India \\ Correspondence should be addressed to Taruna Arora, tarunaarora27@gmail.com
}

Received 29 September 2012; Accepted 11 November 2012

Academic Editors: L. Chen, L. Membrado, T. Oi, and H. M. Rawel

Copyright (C) 2012 Taruna Arora et al. This is an open access article distributed under the Creative Commons Attribution License, which permits unrestricted use, distribution, and reproduction in any medium, provided the original work is properly cited.

\begin{abstract}
Extensive investigation has been carried out to elucidate the mechanisms involved in pseudoligand affinity chromatography using textile dyes, and, empirically, it has been attributed to the chemical and steric structures of dye and protein. Possibly, a variety of interactions especially ionic and/or hydrophobic influence with a varying share in the binding and differ from protein to protein and from dye to dye. In this study, we have attempted to understand the effect of various biophysical parameters like the nature of the eluant, $\mathrm{pH}$, and ionic strength on the binding of crude luteinizing hormone (LH) with various triazine-based dyes and thus predict their nature. Based on the elution patterns, cibacron and reactive brown suggested a dual electrostatic and hydrophobic nature. Reactive blue and reactive yellow reflected a major electrostatic/ionic nature with yellow offering 50-fold purification in a single step, while reactive red and reactive green had a predominant hydrophobic nature. Appreciably, reactive red was binding LH very tightly unlike other dyes, and addition of the arginine in the elution buffer substantially weakened the protein-dye interactions. $\mathrm{pH}$ was observed to be a principal factor assisting the protein-dye binding as well as hydrophobicity of the dye and the proteins.
\end{abstract}

\section{Introduction}

Dye ligand chromatography is rapidly arising as a suitable substitute to specific affinity chromatographies owing to their easy accessibility and economical and effortless immobilization. Despite being synthetic in nature, the triazinebased dyes have a high affinity for many proteins and enzymes [1-7]. In the immobilized form, the dye has rapidly been identified and used as an affinity ligand in chromatographic isolation of a variety of proteins including dehydrogenases, kinases, serum albumin, interferon, several plasma proteins, and a host of other proteins owing to their ability to mimic the configuration of substrates, cofactors, or binding agents, thereby leading to high recovery and many a time purity in tandem, both achieved in a single chromatographic step [8-11].

Most of the dye and protein interaction studies have been performed on the blue sepharose (cibacron blue linked to beaded agarose) involving different dehydrogenase [12, 13].
The affinity ligands both synthetic as well as biological are being designed using a variety of procedures; however, an interesting alternative is presently being offered in the form of biomimetic dyes or chimaeric dye-ligands involving a chloro-triazinlyl scaffold which is often replaced with various amino acids, carbocyclic, and heterocyclic groups, thereby producing ligand libraries. The design of these dyes is performed on the basis of either complementarity by studying a natural ligand-protein complex or mimicking a natural biological recognition interaction $[14,15]$.

As a prelude to realizing the full potential of these textile dyes, an understanding of the interactions of the dye with its cognate protein must be gained. It has been recognized that these dyes are capable of varying hydrophobic and/or ionic interactions with numerous proteins, but such information on all of the dyes is incomplete [16-18]. Also, a detailed study of available dyes for application to isolate a given protein is necessary.

are regulatory hormones which control the reproductive processes in all vertebrates [19]. There is still a huge demand 
for native gonadotropins and thyrotropins, but homologous, for therapeutic purposes for use in buffaloes. A systematic study of the use of dyes for one-step isolation is necessary.

The present study involves the interactions of these dyes with buffalo luteinizing hormone (LH), a gonadotropin to enable development of a single-step procedure for the purification of this hormone. Normally, the conventional protocol involves the use of several chromatographic separations to attain a homogenous preparation $[20,21]$. It is also an effort to elucidate the basic nature of these dyes by analyzing them under various conditions. Cibacron blue has already been used for the purification of buLH [22].

\section{Materials and Methods}

2.1. Materials. Buffalo pituitary, freshly frozen in liquid nitrogen, was procured from local abattoir. Reactive dyeligand test kit (RDL-6) was purchased from Sigma (St. Louis, MO, USA), consisting of six dyes: reactive blue 4-agarose, reactive brown 10-agarose, reactive green 19agarose, reactive red 120-agarose, reactive yellow 86-agarose, and cibacron blue 3GA-agarose. Anti-beta bovine LH antibody was a kind gift from Dr. J. G. Pierce. Goat anti-rabbit HRP conjugate antibody was procured from Bangalore Genie Ltd. 96-well ELISA plates were bought from Greiner, Germany. OPD (orthophenylenediamine) was purchased from Sigma Chemicals. All other reagents used were of analytical grade and were procured locally.

\subsection{Method}

2.2.1. Preparation of Crude LH (50\% Pellet). Whole pituitary glands of buffaloes of mixed age and sex were procured from the slaughterhouse within 30 minutes of slaughter and kept frozen at $-20^{\circ} \mathrm{C}$ until further processing. The modified protocol of Papkoff as described by Chaudhary and Muralidhar [20] was used for the purification of buLH. The entire extraction process was performed at $4^{\circ} \mathrm{C}$, unless otherwise mentioned. The glands were thawed in $0.15 \mathrm{M}$ ammonium sulfate solution containing $1 \mathrm{mM}$ of PMSF (phenyl methyl sulphonyl fluoride). Glands were cut into small pieces and minced followed by homogenization into a thick paste. The $\mathrm{pH}$ of homogenate was adjusted to 4.0, using $1 \mathrm{~N} \mathrm{HCl}$ and then stirred in cold for 1-2 hours. Later, the homogenate was centrifuged at $10,000 \mathrm{~g}$ for 20 minutes at $4^{\circ} \mathrm{C}$. The $\mathrm{pH}$ of the supernatant was adjusted to 3.0 using $0.5 \mathrm{M}$ meta phosphoric acid, stirred for 1-2 hours and centrifuged at $10,000 \mathrm{~g}$ for 20 minutes. The $\mathrm{pH}$ of the supernatant was finally adjusted to 6.7 using $1 \mathrm{~N} \mathrm{NaOH}$. This supernatant was gradually saturated with ammonium sulfate to $50 \%$ using a standard nomogram [23], stirred for 2-3 hrs, and ultimately centrifuged at $3000 \mathrm{~g}$ for 20 minutes. The entire pellet obtained was dissolved in minimum quantity of distilled water and dialyzed against the same for $40 \mathrm{hrs}$ with frequent changes. Dialyzed material was later lyophilized and stored at $-20^{\circ} \mathrm{C}$. The $50 \%$ ammonium sulfate pellet thereby obtained was used as the starting material for the purification of LH.
2.2.2. Dye-Ligand Affinity Chromatography. The dye-linked agarose gels were allowed to swell in $50 \mathrm{mM}$ phosphate buffer for 48 hours. Two $\mathrm{mL}$ columns of immobilized dyes were prepared separately for each dye. Columns were washed extensively with large volumes of equilibrating buffer in order to remove any unbound dye. A flow rate of $20-25 \mathrm{~mL} / \mathrm{hr}$ was maintained. An amount of $100 \mu \mathrm{L}$ of a solution of crude buffalo LH (buLH) (50\% pellet) of $20 \mathrm{mg} / \mathrm{mL}$ in the first buffer was loaded onto each of the columns and incubated for half an hour. All the collected fractions were measured for their absorbance at $280 \mathrm{~nm}$ and immunoreactivity using $\mathrm{LH}$ specific antiserum. The dye-LH interaction was studied by changing parameters as follows.

2.2.3. Buffer Composition. The columns were washed and equilibrated with $8-10$ bed volumes of $50 \mathrm{mM}$ phosphate buffer $\mathrm{pH}$ 7.0, and unbound proteins were removed using the same buffer. This was followed by subsequent elution with $80 \%$ ethylene glycol and finally $1 \mathrm{M} \mathrm{NaCl}$.

2.2.4. Buffer $p H$. The columns were washed and equilibrated with $50 \mathrm{mM}$ citrate buffer $\mathrm{pH} 5.0$, and unbound proteins were removed. Elution of the bound protein was executed by varying the $\mathrm{pH}$, that is, by using $50 \mathrm{mM}$ phosphate buffer $\mathrm{pH}$ 7.0 and $50 \mathrm{mM}$ sodium glycinate buffer $\mathrm{pH} 9.0$, respectively. Later, $80 \%$ ethylene glycol and $1 \mathrm{M} \mathrm{NaCl}$ were used.

2.2.5. Buffer Strength. The columns were equilibrated with $25 \mathrm{mM}$ citrate buffer $\mathrm{pH}$ 5.0, and unbound proteins were removed. Later, the elution of the bound proteins was done using $50 \mathrm{mM}$ and $100 \mathrm{mM}$ citrate buffer $\mathrm{pH}$ 5.0. Subsequent elutions were carried out by increasing the buffer strength of the phosphate buffer pH 7.0 and sodium glycinate buffer pH 9.0 as well to 50 and $100 \mathrm{mM}$. This was followed by $80 \%$ ethylene glycol and $1 \mathrm{M} \mathrm{NaCl}$. In addition, in reactive red dye, $50 \mathrm{mM}$ arginine as a background was introduced in all the steps as an improvement.

2.2.6. Protein Estimation. Proteins were essentially estimated according to the Lowry's method [24].

2.2.7. ELISA. Direct binding ELISA was used to detect and estimate the quantity of buLH. All the fractions, unbound and bound, were analyzed for their specific LH immunoreactivity using antibeta bovine LH (a kind gift from Dr. J. G. Pierce). The ELISA was essentially performed as described by Arora et al. [21].

All the experiments performed have an average of two results.

\section{Results and Discussion}

Reactive dyes are known to bind proteins with high affinity but with varying binding capacity and specificity. The chemical composition of most of these reactive dyes is comprised of azo dyes, anthraquinone, or phthalocyanine, linked to a reactive group, often a mono- or dichlorotriazine 




Figure 1: Percentage LH immunoreactivity (\%) of the eluted peak fractions when $50 \%$ pellet was loaded on various agarose-linked dyes and eluted by changing the nature of the eluants.

ring. This unique binding of various proteins to the dyes is still enigmatic and is a multifarious display of electrostatic, hydrophobic hydrogen bonding. [5-7, 25]. To achieve an efficient isolation of desired protein, buLH in our case, it is recommended that the adsorption as well as the elution procedures should carefully be optimized and designed [26]. Hence, elution was performed by addition of competing substance, changing $\mathrm{pH}$ or ionic strength, and addition of $\mathrm{NaCl}[8,9]$. Addition of organic solvents, for example, ethylene glycol, was also used to weaken hydrophobic interactions.

Each dye reflected a distinctive inimitable profile and thus indicated a unique or a predominant character (Figures 1,2 , and 3). The individual results of all the six dyes have been discussed separately keeping into consideration the three figures.

\subsection{Cibacron Blue $3 G A$}

3.1.1. Cibacron Exhibited Both Electrostatic, Which Was Predominant, and Hydrophobic Interactions. On changing the nature of the buffers, two isoforms of buLH were eluted using ethylene glycol and $\mathrm{NaCl}$, respectively. About $35 \%$ of the bound LH was eluted using $80 \%$ ethylene glycol, while $49.5 \%$ of it was eluted using $1 \mathrm{M} \mathrm{NaCl}$. This shows that buLH interacts both hydrophobically as well as electrostatically (predominantly) with cibacron [27]. An increase in the $\mathrm{pH}$ to 9.0 of the eluting buffer led to the removal of as much as $40 \%$ of contaminant nonimmunoreactive proteins. Further, at alkaline $\mathrm{pH}$, there is a weakening of the hydrophobic interactions of the bound $\mathrm{LH}$, thus leading to the release of $\mathrm{LH}$ prior to the addition of ethylene glycol. The form of LH, which is eluted subsequently using $\mathrm{NaCl}$, is comparatively the purest form of buLH. Apparently, there is a significant role of electrostatic forces in cibacron-LH binding, which seems to be $\mathrm{pH}$ regulated, assisting in making the hydrophobic forces stronger. Changes in ionic strength at varying $\mathrm{pH}$ did not have a major impact on the buLH-cibacron interactions; however, it was observed that it played a major role in the binding/removal of nonspecific contaminant proteins.

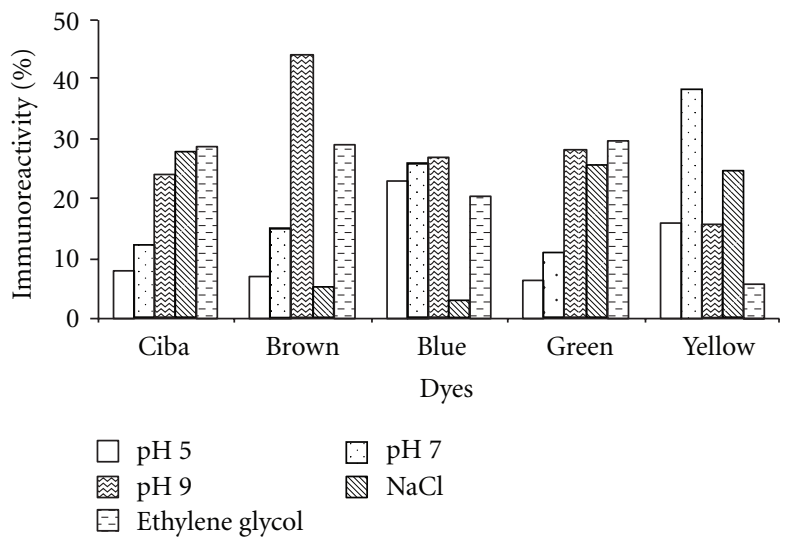

FIgURE 2: Comparative profile in terms of the presence of percent immunoreactive LH (\%) in various peak fractions obtained by using various agarose-linked dyes through the alteration in the $\mathrm{pH}$ ( $\mathrm{pH}$ 5.0, 7.0, and 9.0) of the eluting buffers.

As per the structure of cibacron, while the presence of three $\mathrm{SO}_{3} \mathrm{H}$ groups per molecule is leading to the presence of negative charge thereby promoting electrostatic interactions, the presence of the anthraquinone, diaminobenzene sulphonate, and triazine rings encourages hydrophobic interactions.

\subsection{Reactive Blue}

3.2.1. Reactive Blue Reflected a Major Electrostatic/Ionic Nature. Reactive blue did not bind buLH as tightly as cibacron. Twenty-four percent of LH was found in the unbound fraction along with the contaminant proteins. Thirty-six percent of bound LH eluted with ethylene glycol and $41 \%$ with $\mathrm{NaCl}$. Elution of isoforms with $\mathrm{pH}$ and ionic strength were observed with an increase in $\mathrm{pH}$. The interactions of buLH with reactive blue were mainly electrostatic, and any hydrophobic interactions observed are possibly $\mathrm{pH}$ dependent and decrease as soon as the $\mathrm{pH}$ is increased. Therefore, a change in the ionic strength $(25 \mathrm{mM}$ to $100 \mathrm{mM}$ ) as well as $\mathrm{pH}$ ( $\mathrm{pH} 5$ to $\mathrm{pH}$ 9) played a crucial role during the elution and resulted in the subsequent emergence of isoforms of buLH.

The structure of reactive blue also contained the anthraquinone ring, the bridging diaminobenzene ring, and the triazine ring; however, unlike cibacron, it was observed that the terminal aminobenzene ring with a sulphonic acid residue was missing thereby leading to a lesser hydrophobic structure as well as more exposure of the charged residue. This increased exposure of the charged residue possibly makes the dye more vulnerable to ionic as well as $\mathrm{pH}$ changes.

\subsection{Reactive Brown}

3.3.1. Reactive Brown, Was Found to Interact with Both Electrostatic and Hydrophobic Groups. With reactive brown, also, like reactive blue, the interactions were found to be mainly electrostatic in nature where the ionic strength and 


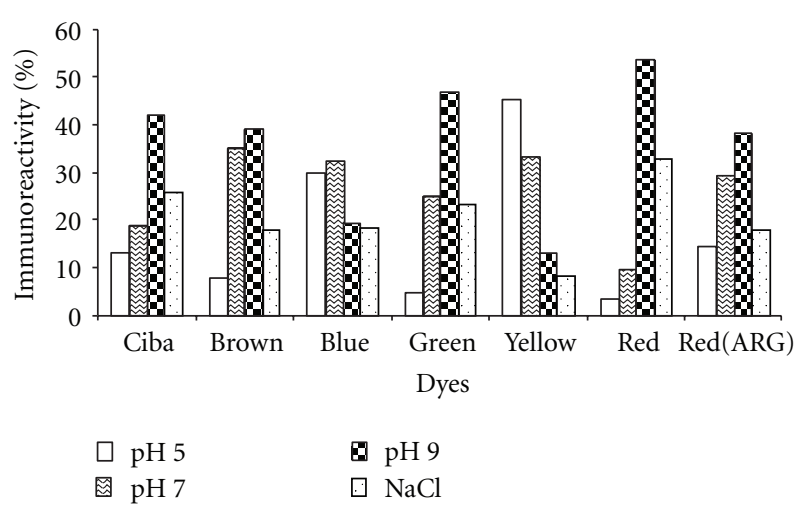

Figure 3: Assessment of the percent immunoreactive LH (\%) of the various eluted peak fractions obtained in all the buffers of varying $\mathrm{pH}$ ( $\mathrm{pH} 5.0,7.0$, and 9.0) when the ionic strength $(25 \mathrm{mM}, 50 \mathrm{mM}$, and $100 \mathrm{mM}$ ) was altered.

$\mathrm{pH}$ played a crucial role in determining the strength of the binding of buLH with the dye. buLH binds to the column quite tightly, and very little was found in the unbound fraction $(<20 \%)$. While at $\mathrm{pH} 7.0,53 \%$ of the bound $\mathrm{LH}$ was eluted using ethylene glycol and $26 \%$ using $\mathrm{NaCl}$, alkaline $\mathrm{pH}(\mathrm{pH} 9.0)$ conditions led to the weakening of electrostatic interactions, and as much as $44 \%$ of the bound $\mathrm{LH}$ was eluted out at this $\mathrm{pH}$. However, the change in ionic strength of the buffer had a noteworthy effect, and even at $\mathrm{pH}$ 7.0, there was a significant elution of the bound $\mathrm{LH}$ with increased ionic strength of $100 \mathrm{mM}$ (35\%). Consequently, it is indicative that the hydrophobic character of the dye does not play a pivotal role in the binding of buLH, and most of the major interactions of the hormone with the dye are electrostatic.

The structure of reactive brown reflects that it contained benzoic acid, azo sulphonyl derivative of naphthol, and the triazine ring, besides containing several negatively charged residues like hydroxyl group, chloride group, and the sulphonyl and a keto group. Therefore, there is a prominent negatively charged character and a less strong hydrophobic character. Hence, a change in the $\mathrm{pH}$ values can modulate the behavior of the dye.

\subsection{Reactive Yellow}

3.4.1. Reactive Yellow Indicated a Predominant Ionic Nature. The dye binds to buLH very weakly even at low $\mathrm{pH}(\mathrm{pH}$ $5.0)$ and low ionic concentration ( $25 \mathrm{mM})$, and consequently a little increase in ionic concentration as well as $\mathrm{pH}$ of the buffer leads to the elution of the hormone. Hydrophobic interactions between $\mathrm{LH}$ and reactive yellow were found to be very weak in nature. The dye shows a great promise as a buLH single-step purification column because we could achieve more than $50 \%$ pure buLH even when the nature of solvent system was altered (Figure 4, Table 2).

The structure of reactive yellow includes disulphonyl naphthalene, acetamide derivative of azo benzene, and triazine ring making an extended conjugated system as evident providing yellow color to the dye.

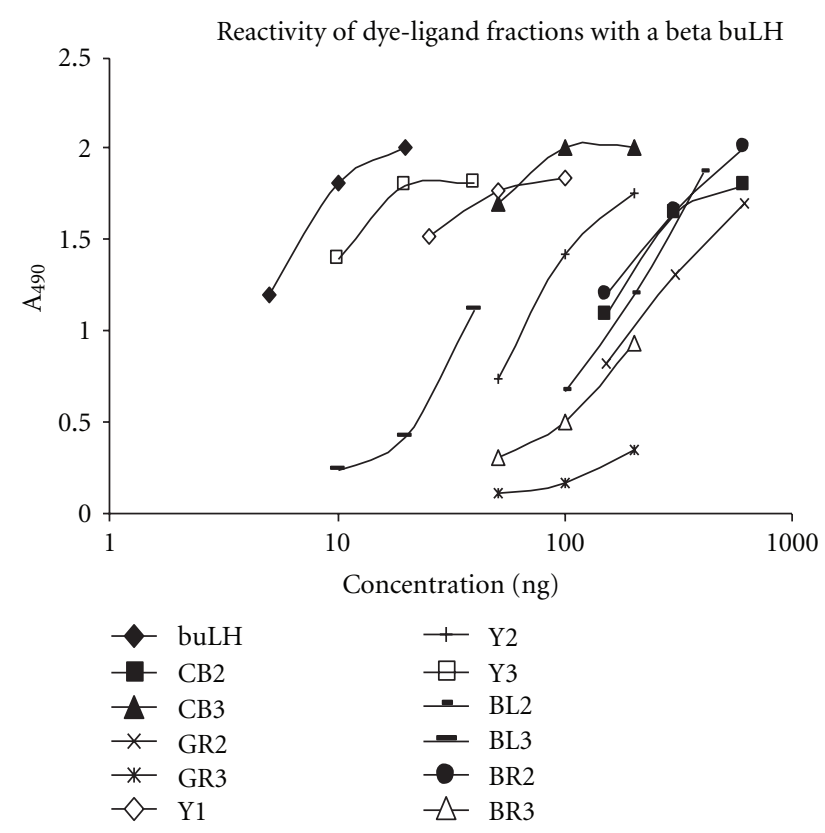

FIGURE 4: LH content in the various eluted fractions. (CB2: cibacron ethylene glycol fraction; $\mathrm{CB} 3$ : cibacron $\mathrm{NaCl}$ fraction; GR2: reactive green ethylene glycol fraction; GR3: reactive green $\mathrm{NaCl}$ fraction; Y1: reactive yellow unbound fraction; Y2: reactive yellow ethylene glycol fraction; $\mathrm{Y3}$ : reactive yellow $\mathrm{NaCl}$ fraction; $\mathrm{BL} 2$ : reactive blue ethylene glycol fraction; $\mathrm{BL} 3$ : reactive blue $\mathrm{NaCl}$ fraction; $\mathrm{BR} 2$ : reactive brown ethylene glycol fraction; $\mathrm{BR} 3$ : reactive brown $\mathrm{NaCl}$ fraction).

\subsection{Reactive Red}

3.5.1. Reactive Red Displayed Hydrophobic Nature. Crude LH bound very tightly to the column at acidic and neutral $\mathrm{pH}$; however, when the $\mathrm{pH}$ was made alkaline, elution of buLH was observed. Introduction of salt as well as increase in alkalinity led to the elution of a relatively pure buLH. The structural property of the red dye indicates the presence of six $\mathrm{SO}_{3}{ }^{-}$groups and several aromatic ring structures. The presence of bulky ring structure is overshadowing any ionic character it might be possessing.

3.5.2. Use of Arginine. Arginine as a molecule is known to weaken hydrophobic interactions and facilitate elution of bound proteins. Inclusion of arginine in the loading sample has been recognized to increase the recovery of the total protein and decrease the aggregation during ion exchange chromatography [28]. Since arginine solubilizes certain proteins from insoluble pellets in the active, folded structure [29], hydrophobic interaction chromatography in the presence of arginine could be a useful technique for purification of the proteins without potential denaturation [30]. Arginine is an effective additive for the gel permeation columns (GPCs) mobile phase [31-33] as it improves separation of the proteins and their soluble aggregates from the GPC.

Because of the inability to use organic solvents (organic solvents led to the leaching of the dye from the gel) with 


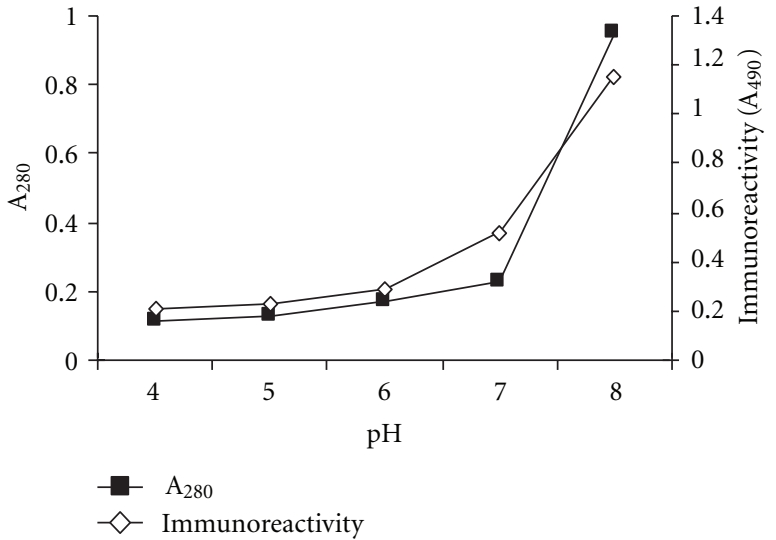

FIGURE 5: Determination of the $\mathrm{pH}$ at which the crude LH should be loaded for maximum binding on the dye resins. The $\mathrm{LH}$ immunoreactivity (absorbance at $490 \mathrm{~nm}$ ) and the absorbance at $280 \mathrm{~nm}$ were plotted against differential $\mathrm{pH}$ values.

this dye to weaken the hydrophobic interactions, arginine was used which facilitated the elution of bound proteins, thereby increasing the recovery of the total protein $[33,34]$. Addition of arginine $(200 \mathrm{mM})$ at $\mathrm{pH} 5.0$ led to the release of only contaminant proteins, while buLH remained bound to the column. Thereafter, increase in $\mathrm{pH}$ and $1 \mathrm{M} \mathrm{NaCl}$ led to release of bound hormone. Red dye bound LH very tightly, and this feature was not seen in any other dye.

\subsection{Reactive Green}

3.6.1. Reactive Green Has a Predominant Hydrophobic Nature. When the nature of the buffers was changed, ethylene glycol leads to the maximum release of the bound $\mathrm{LH}$ (55\%) compared to the unbound $(12.5 \%)$ and the $\mathrm{NaCl}$ $(20 \%)$ fractions, thereby suggesting the presence of a strong hydrophobic character on the dye matrix. Alkaline $\mathrm{pH}$ of the eluting buffer led to a drastic decrease in the hydrophobic peak $(30 \%)$, and a considerable amount of LH was eluted using $\mathrm{pH} 9.0$ buffer. A significant effect of the increased $\mathrm{pH}$ on the hydrophobicity of the protein as well as the dye has been observed.

The structure of the reactive green shows a large, bulky structure with six $\mathrm{SO}_{3}{ }^{-}$groups and several ring structures, which are introducing a large hydrophobic character to the dye. The presence of this bulky ring structure is overcoming any ionic character it might be possessing. The dye matrix is predominantly behaving like a hydrophobic matrix.

3.7. Quantitative Analysis of the Various Eluted "LH" Fractions. Quantitative elution of the loaded protein was observed to decrease in the following order: reactive yellow $>$ cibacron blue $3 \mathrm{GA}>$ reactive blue $>$ reactive brown $>$ reactive green. Reactive red and reactive green were found to be strongly hydrophobic, and even strong eluants like ethylene glycol and sodium chloride could not elute out the bound proteins completely (Table 1). Reactive red is an unusual dye in many ways as initially on changing the nature of buffers, no elution was observed, and the dye even leached out following the use of ethylene glycol. Thereby, $1 \mathrm{M}$ urea was subsequently used for the elution of hydrophobic forms. The change in the $\mathrm{pH}$ and ionic strength improved the overall elution of the bound proteins except in the case of reactive red dyes. Subsequently, addition of arginine radically improved the elution of the bound protein from the reactive red dye (Table 1).

Purified buLH was used as the reference standard to estimate the immunoreactive buLH content in various dye purified fractions. The ratio of the approximate amount of buLH, as well as various dye purified fractions which are required to achieve an $\mathrm{A}_{490}$ of one using antibeta bovine $\mathrm{LH}$, was used as the criteria to estimate the buLH content in them. Subsequently, the fold purification was calculated using the following formula:

\section{Fold purification}

$$
\begin{gathered}
=\text { Amount of buLH required to achieve } \mathrm{A}_{490} \text { of one } \\
\times(\text { Amount of various fractions required to } \\
\text { achieve } \left.\mathrm{A}_{490} \text { of one }\right)^{-1} \times 100 .
\end{gathered}
$$

Hence, reactive yellow was able to provide us 50-fold purification in a single step (reactive yellow $\mathrm{NaCl}$ fraction (Y3)) followed by reactive yellow unbound fraction (Y1) which was 24-fold purified. Besides this, cibacron blue 3GA and reactive blue $\mathrm{NaCl}$ fractions are the ones which are promising in nature and can further be exploited for singlestep purification (Figure 4, Table 2).

3.8. Optimization of $p H$ for the Loading of the Sample. For determining the optimum $\mathrm{pH}$ at which $\mathrm{LH}$ binds efficiently to the agarose-bound dye columns, unbound fractions of each of them were assessed for immunoreactivity against buLH. The LH immunoreactivity $\left(\mathrm{A}_{490}\right)$ and the absorbance at $280 \mathrm{~nm}$ in various unbound fractions of different dyes at varying $\mathrm{pH}$ conditions were plotted (Figure 5). In all the dyes, minimum LH immunoreactivity in the unbound fractions was found at $\mathrm{pH} 4-5$ using citrate buffer, thereby indicating that maximum binding of $50 \%$ pellet (crude LH) occurred at the acidic $\mathrm{pH}$.

3.9. Effect of $p H$ on Hydrophobicity. Reaction conditions, such as $\mathrm{pH}$, ionic strength, temperature, and solution components, are known to influence the surface characteristics of the cells like Giardia cysts and Cryptosporidium oocysts $[35,36]$, especially the surface charge and hydrophobicity. The structure of proteins is primarily affected by hydrophobic, steric, and electrical parameters. Among these factors, hydrophobicity is known to be significantly related to the functional properties of proteins [37].

$\mathrm{pH}$ is a predominant factor assisting the hydrophobicity of the dye as well as the proteins [38]. In all of the dye-protein interactions, there is a significant decrease in hydrophobicity observed with a concomitant rise in $\mathrm{pH}$. Therefore, there is an appreciable reduction in all the ethylene glycol fractions 
TABLE 1: Quantitative elution pattern of protein on different dye-agarose columns.

\begin{tabular}{lcccc}
\hline S. no. & Name of the dye & $\begin{array}{c}\text { Changing the composition of the } \\
\text { buffers (\%) }\end{array}$ & $\begin{array}{c}\text { Changing the pH of the } \\
\text { buffers (\%) }\end{array}$ & $\begin{array}{c}\text { Changing the ionic strength of } \\
\text { the buffers (\%) }\end{array}$ \\
\hline$(1)$ & Cibacron blue 3GA & 70.46 & 79.03 & 84.94 \\
$(2)$ & Reactive blue & 53 & 61.13 & 80.52 \\
$(3)$ & Reactive brown & 47.52 & 55 & 87.64 \\
$(4)$ & Reactive yellow & 95 & 96.1 & 96.76 \\
$(5)$ & Reactive red & - & 39.76 & $49.82 / 92.7$ (arginine) \\
$(6)$ & Reactive green & 40.48 & 74 & 77.94 \\
\hline
\end{tabular}

TABLE 2: Fold purification achieved of the various eluted fractions obtained when crude LH was loaded on different agarose-linked textile dyes, and the nature of the eluants was changed.

\begin{tabular}{lccc}
\hline S. no. & Name of the fraction & Immunoreactive LH content (in ng) & Fold purification \\
\hline$(1)$ & Buffalo LH (buLH) & 6 & - \\
$(2)$ & Cibacron ethylene glycol fraction (CB2) & 35 & 3 \\
$(3)$ & Cibacron NaCl fraction (CB3) & 250 & 17.14 \\
$(4)$ & Reactive blue ethylene glycol fraction (BL2) & 60 & 2.4 \\
$(5)$ & Reactive blue NaCl fraction (BL3) & 200 & 3 \\
$(6)$ & Reactive brown ethylene glycol fraction (BR2) & 400 & 1.5 \\
$(7)$ & Reactive brown NaCl fraction (BR3) & 25 & 24 \\
$(8)$ & Reactive yellow unbound fraction (Y1) & 400 & 1.5 \\
$(9)$ & Reactive yellow ethylene glycol fraction (Y2) & 12 & 50 \\
$(10)$ & Reactive yellow NaCl fraction (Y3) & 110 & 5.4 \\
$(11)$ & Reactive green ethylene glycol fraction (GR2) & 1000 & 0.6 \\
$(12)$ & Reactive green NaCl fraction (GR3) & & 30 \\
\hline
\end{tabular}

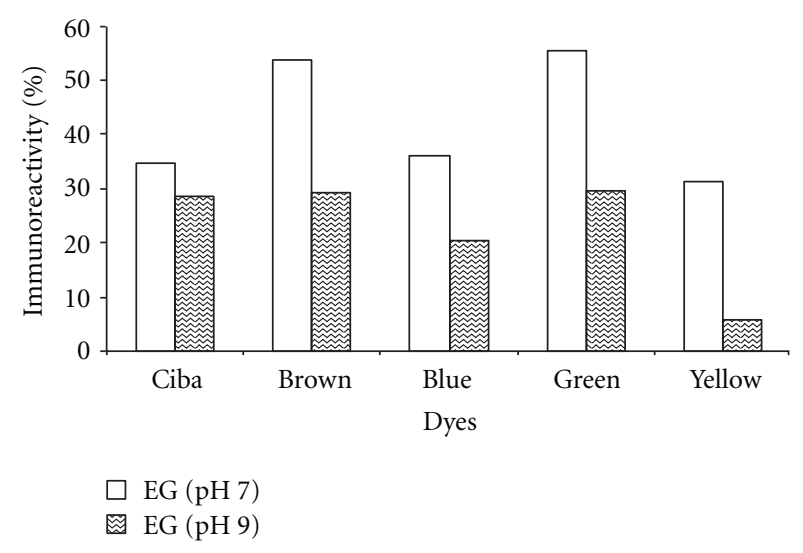

Figure 6: Comparative profile of the ethylene glycol fractions of various dyes in terms of percent immuno reactive $\mathrm{LH}$ fraction at $\mathrm{pH} 7.0$ as well as at $\mathrm{pH} 9.0$.

when the $\mathrm{pH}$ of the buffer is increased from 7.0 to 9.0 (Figure 6). Low $\mathrm{pH}$ assists in the binding of proteins. Ionic strength plays a crucial role in isolation of isoforms especially in reactive blue, cibacron blue, reactive red in the presence of arginine, and reactive yellow especially at low $\mathrm{pH}$.

\section{Conclusions}

The study illustrates that the triazine dyes are not only excellent group-specific ligands but exhibit a wide range of interactions, thereby making the binding of these dyes to proteins highly structure dependent [39]. Strongly coordinating and specific, interactions like hydrogen bonding, van der Waals force, electrostatic force and hydrophobic interaction [40-43] are responsible for the molecular recognition $[5,13,44]$ and occur at the natural ligand-binding site of the protein. The dyes offered different characteristics depending upon the cumulative effect of the number of benzene rings (predominant), sulphonate groups, and other ionic groups attached to them despite the fact that all of them have a basic triazine nucleus. An increase in the number of benzene rings beyond five led to the introduction of hydrophobic character to the dye. In fact, a higher number of benzene rings even masked the electrostatic effect of the various ionic groups. Arginine as a molecule was found to be useful in loosening the hydrophobic interactions especially with the red dye. Many of these dyes exhibited a potential of development of single-step purification for the buLH hormone.

\section{Acknowledgments}

This paper was supported by grants from UGC Postdoctoral Fellowship for women and DST Women Scientist Scheme, Government of India, New Delhi to T. Arora. Funds and facilities provided by University of Delhi are also gratefully acknowledged. 


\section{References}

[1] C. R. Lowe, "An introduction to affinity chromatography," in Laboratory Techniques in Bio-Chemistry and Molecular Biology, T. S. Work and E. Work, Eds., chapter 7, pp. 269-522, NorthHolland Biomedical Press, Amsterdam, The Netherlands, 1979.

[2] C. R. Lowe, D. A. P. Small, and A. Atkinson, "Some preparative and analytical applications of triazine dyes," International Journal of Biochemistry, vol. 13, no. 1, pp. 33-40, 1981.

[3] P. D. G. Dean and D. H. Watson, "Protein purification using immobilised triazine dyes," Journal of Chromatography A, vol. 165, no. 3, pp. 301-319, 1979.

[4] G. Raya-Tonetti and N. I. Perotti, "Rapid screening of textile dyes employed as affinity ligands to purify enzymes from yeast," Biotechnology and Applied Biochemistry, vol. 29, no. 2, pp. 151-156, 1999.

[5] R. K. Scopes, "Dye-ligands and multifunctional adsorbents: an empirical approach to affinity chromatography," Analytical Biochemistry, vol. 165, no. 2, pp. 235-246, 1987.

[6] Y. Kroviarski, S. Cochet, C. Vadon, A. Truskolaski, P. Boivin, and O. Bertrand, "Purification of human 6-phosphogluconate dehydrogenase from human haemolysate with chromatography on an immobilized dye as the essential step and use of automation. Simultaneous purification of lactate dehydrogenase," Journal of Chromatography, vol. 449, no. 2, pp. 413-422, 1988.

[7] H. Mottl and W. Keck, "Rapid screening of a large number of immobilized textile dyes for the purification of proteins: use of penicillin-binding protein 4 of Escherichia coli as a model enzyme," Protein Expression and Purification, vol. 3, no. 5, pp. 403-409, 1992.

[8] M. J. Dunn, "Electroelution of proteins from polyacrylamide gels," in Methods in Molecular Biology: Protein Purification Protocols, S. Doonan, Ed., pp. 357-362, Humana Press, Totowa, NJ, USA, 1996.

[9] F. Qadri and P. D. G. Dean, "The use of various immobilized-triazine affinity dyes for the purification of 6phosphogluconate dehydrogenase from Bacillus stearothermophilus," Biochemical Journal, vol. 191, no. 1, pp. 53-62, 1980.

[10] I. Roy and M. N. Gupta, "Purification of alkaline phosphatase from chicken intestine by expanded-bed affinity chromatography on dye-linked cellulose," Biotechnology and Applied Biochemistry, vol. 32, no. 2, pp. 81-87, 2000.

[11] P. Bailon, G. K. Ehrlich, W. J. Fung, and W. Berthold, Eds., Affinity Chromatography: Methods and Protocols, vol. 147, Humana Press, Totowa, NJ, USA, 2000.

[12] R. Haeckel, B. Hess, W. Lauterborn, and K. H. Wüster, "Purification and allosteric properties of yeast pyruvate kinase," Biological Chemistry, vol. 349, no. 5, pp. 699-714, 1968.

[13] G. Kopperschläger, R. Freyer, W. Diezel, and E. Hofmann, "Some kinetic and molecular properties of yeast phosphofructokinase," FEBS Letters, vol. 1, no. 3, pp. 137-141, 1968.

[14] Y. D. Clonis, "Affinity chromatography matures as bioinformatic and combinatorial tools develop," Journal of Chromatography A, vol. 1101, no. 1-2, pp. 1-24, 2006.

[15] K. Mondal and M. N. Gupta, "The affinity concept in bioseparation: evolving paradigms and expanding range of applications," Biomolecular Engineering, vol. 23, no. 2-3, pp. 59-76, 2006.

[16] I. Y. Galaev and B. Mattiasson, "Shielding affinity chromatography," Nature Biotechnology, vol. 12, no. 11, p. 1086, 1994.
[17] I. Y. Galaev, C. Warrol, and B. Mattiasson, "Temperatureinduced displacement of proteins from dye-affinity columns using an immobilized polymeric displacer," Journal of Chromatography A, vol. 684, no. 1, pp. 37-43, 1994.

[18] B. Champluvier and M. R. Kula, "Dye-ligand membranes as selective adsorbents for rapid purification of enzymes: a case study," Biotechnology and Bioengineering, vol. 40, no. 1, pp. 3340, 1992.

[19] J. G. Pierce and T. F. Parsons, "Glycoprotein hormones: structure and function," Annual Review of Biochemistry, vol. 50, pp. 465-495, 1981.

[20] R. Chaudhary and K. Muralidhar, "Use of SP-sephadexto fractionate and obtain semi-pure preparation from whole pituitaries of Indian water buffaloes (Bubalus bubalis)," Preparative Biochemistry and Biotechnology, vol. 34, no. 4, pp. 315-329, 2004.

[21] T. Arora, N. Vashistha, and K. Muralidhar, "Chromatographic separation of thyroid stimulating hormone from luteinizing hormone," Journal of Liquid Chromatography and Related Technologies, vol. 33, no. 5, pp. 680-692, 2010.

[22] R. Chaudhary, S. Jain, K. Muralidhar, and M. N. Gupta, "Purification of bubaline luteinizing hormone by gel filtration chromatography in the presence of blue dextran," Process Biochemistry, vol. 41, no. 3, pp. 562-566, 2006.

[23] M. Dixon, "A nomogram for ammonium sulphate solutions," The Biochemical Journal, vol. 54, no. 3, pp. 457-458, 1953.

[24] O. H. Lowry, N. J. Rosebrough, A. L. Farr, and R. J. Randall, "Protein measurement with the Folin phenol reagent," The Journal of Biological Chemistry, vol. 193, no. 1, pp. 265-275, 1951.

[25] R. K. Scopes, "Strategies for enzyme isolation using dyeligand and related adsorbents," Journal of ChromatographyBiomedical Applications, vol. 376, pp. 131-140, 1986.

[26] A. Denizli and E. Pişkin, "Dye-ligand affinity systems," Journal of Biochemical and Biophysical Methods, vol. 49, no. 1-3, pp. 391-416, 2001.

[27] T. Arora, N. Vashistha, R. Chaudhary, and K. Muralidhar, "Pseudo-affinity chromatographic approach to probe heterogeneity in buffalo pituitary luteinizing hormone: probable pseudolectin-like behavior of immobilized Cibacron Blue 3GA," Journal of Chromatography B, vol. 878, no. 28, pp. 26792684, 2010.

[28] T. Arakawa, K. Tsumoto, K. Nagase, and D. Ejima, "The effects of arginine on protein binding and elution in hydrophobic interaction and ion-exchange chromatography," Protein Expression and Purification, vol. 54, no. 1, pp. 110-116, 2007.

[29] M. Umetsu, K. Tsumoto, S. Nitta et al., "Nondenaturing solubilization of $\beta 2$ microglobulin from inclusion bodies by L-arginine," Biochemical and Biophysical Research Communications, vol. 328, no. 1, pp. 189-197, 2005.

[30] T. Arakawa, D. Ejima, K. Tsumoto, M. Ishibashi, and M. Tokunaga, "Improved performance of column chromatography by arginine: dye-affinity chromatography," Protein Expression and Purification, vol. 52, no. 2, pp. 410-414, 2007.

[31] D. Ejima, R. Yumioka, T. Arakawa, and K. Tsumoto, "Arginine as an effective additive in gel permeation chromatography," Journal of Chromatography A, vol. 1094, no. 1-2, pp. 49-55, 2005.

[32] G. K. Ackers and T. E. Thompson, "Determination of stoichiometry and equilibrium constants for reversibly associating systems by molecular sieve chromatography," Proceedings of the National Academy of Sciences of the United States of, vol. 53, pp. 342-349, 1965. 
[33] M. Li, Z. G. Su, and J. C. Janson, "In vitro protein refolding by chromatographic procedures," Protein Expression and Purification, vol. 33, no. 1, pp. 1-10, 2004.

[34] T. S. Work and E. Work, Eds., Techniques in Biochemistry and Molecular Biology, North-Holland, Amsterdam, The Netherlands.

[35] K. Ohmori and C. E. Glatz, "Effects of $\mathrm{pH}$ and ionic strength on microfiltration of C. glutamicum," Journal of Membrane Science, vol. 153, no. 1, pp. 23-32, 1999.

[36] B. M. Hsu and C. Huang, "Influence of ionic strength and $\mathrm{pH}$ on hydrophobicity and zeta potential of Giardia and Cryptosporidium," Colloids and Surfaces A, vol. 201, no. 1-3, pp. 201-206, 2002.

[37] S. Nakai, E. Li-Chan, and G. E. Arteaga, "Measurement of surface hydrophobicity," in Methods of Testing Protein Functionality, G. M. Hall, London, UK, 1996.

[38] N. Alizadeh-Pasdar and E. C. Y. Li-Chan, "Comparison of protein surface hydrophobicity measured at various $\mathrm{pH}$ values using three different fluorescent probes," Journal of Agricultural and Food Chemistry, vol. 48, no. 2, pp. 328-334, 2000.

[39] F. Qadri, "The reactive triazine dyes: their usefulness and limitations in protein purifications," Trends in Biotechnology, vol. 3, no. 1, pp. 7-12, 1985.

[40] Y. Yue, X. Chen, J. Qin, and X. Yao, "A study of the binding of C.I. Direct Yellow 9 to human serum albumin using optical spectroscopy and molecular modeling," Dyes and Pigments, vol. 79, no. 2, pp. 176-182, 2008.

[41] S. Y. Suen, S. Y. Lin, and H. C. Chiu, "Effects of spacer arms on Cibacron Blue 3GA immobilization and lysozyme adsorption using regenerated cellulose membrane discs," Industrial and Engineering Chemistry Research, vol. 39, no. 2, pp. 478-487, 2000.

[42] C. H. Chen and W. C. Lee, "Affinity chromatography of proteins on non-porous copolymerized particles of styrene, methyl methacrylate and glycidyl methacrylate," Journal of Chromatography A, vol. 921, no. 1, pp. 31-37, 2001.

[43] S. Y. I. Suen and Y. I. D. A. Tsai, "Comparison of ligand density and protein adsorption on dye-affinity membranes using different spacer arms," Separation Science and Technology, vol. 35, no. 1, pp. 69-87, 1999.

[44] S. Y. Bi, D. Q. Song, Y. Tian, X. Zhou, Z. Y. Liu, and H. Zhang, "Molecular spectroscopic study on the interaction of tetracyclines with serum albumins," Spectrochimica Acta A, vol. 61, no. 4, pp. 629-636, 2005. 


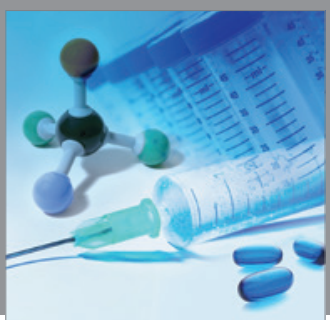

International Journal of

Medicinal Chemistry

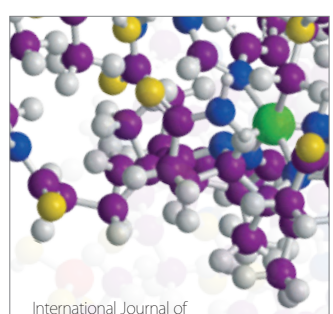

Carbohydrate Chemistry

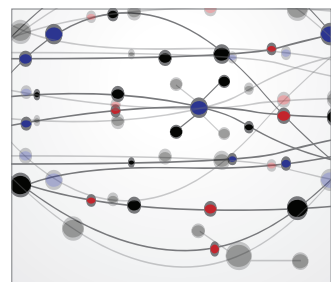

The Scientific World Journal
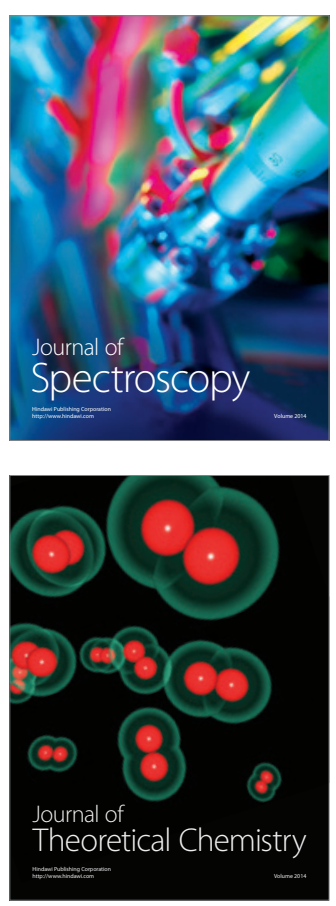
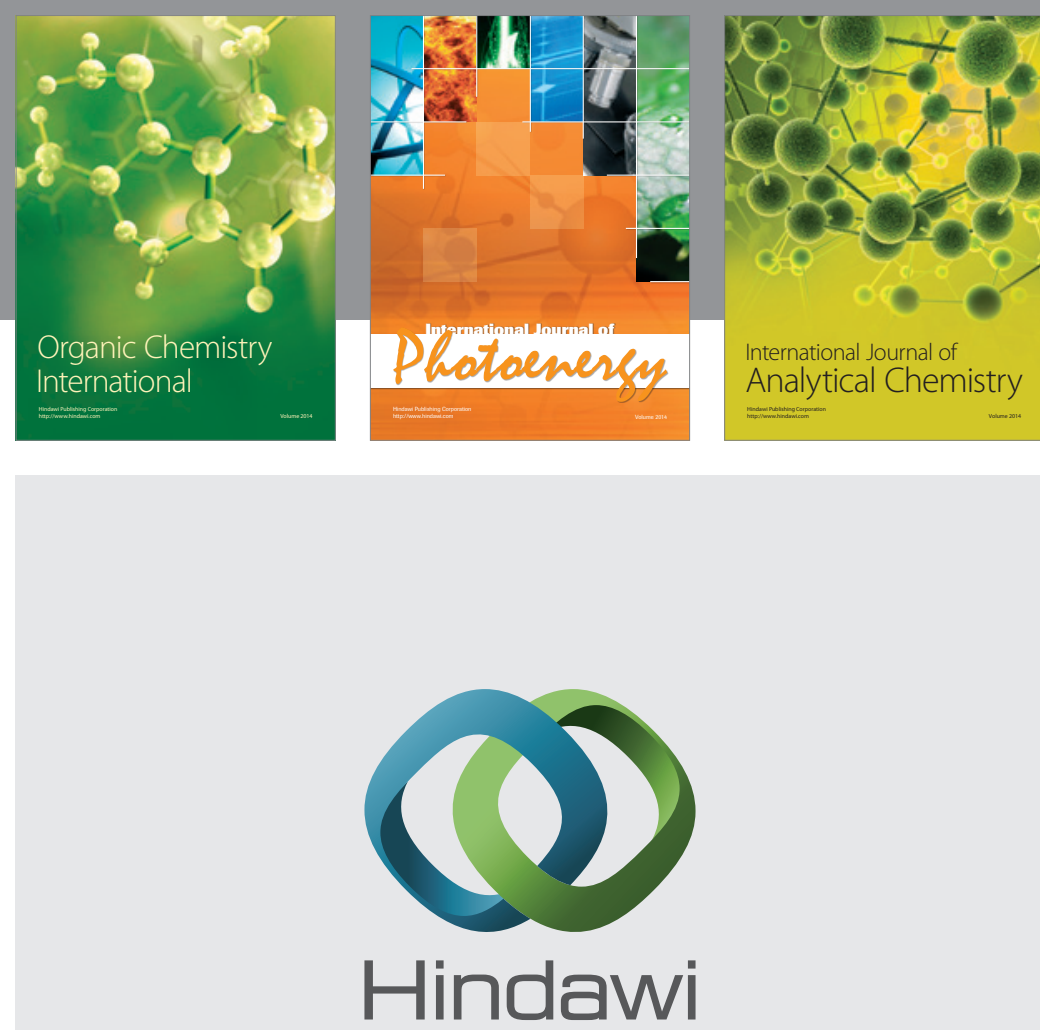

Submit your manuscripts at

http://www.hindawi.com
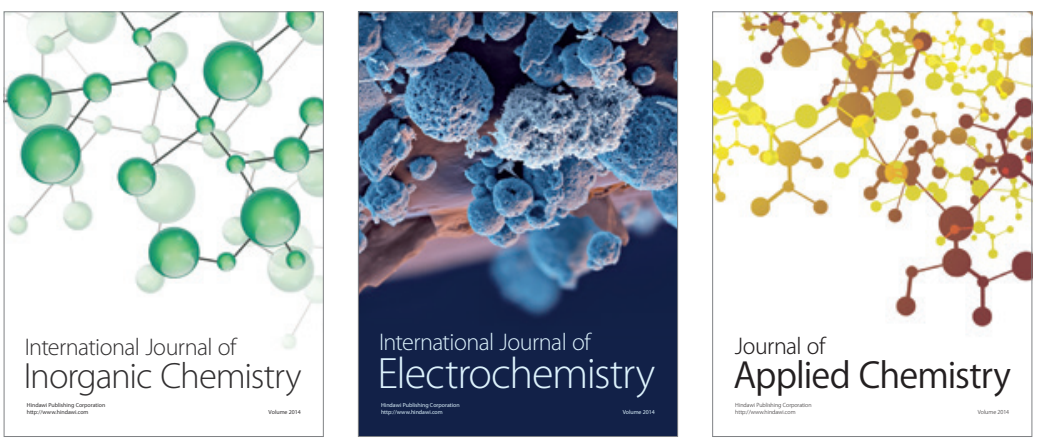

Journal of

Applied Chemistry
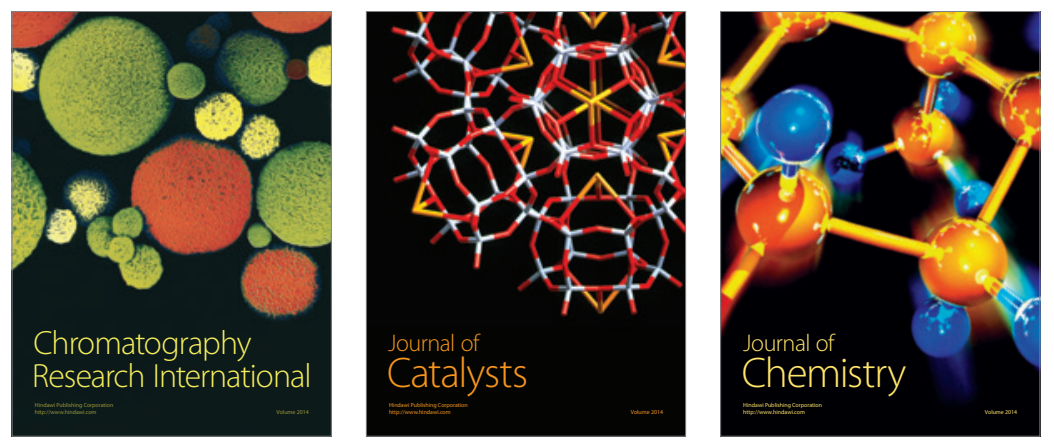
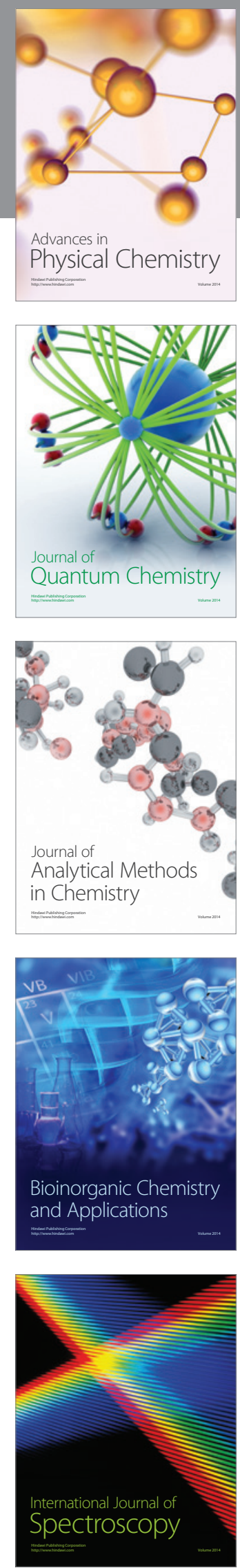